\title{
Roma pelos olhos de Cecília Meireles
}

\author{
Delvanir Lopes
}

A arte de viajar é uma arte de admirar, uma arte de amar. Cecília Meireles

A preparação de Cecília Meireles inicia-se muito antes das viagens propriamente ditas. A preparação era intelectual, recheada de leituras das mais variadas fontes e aguçada pela curiosidade de quem não se contentava em apenas viajar e conhecer um novo lugar, mas cujo desejo estava em fazer parte da história e demonstrar respeito e admiração pela tradição e costumes que iria vivenciar. O que a escritora queria era abarcar o mundo e experimentá-lo com toda a intensidade possível. É o caminho que percorre:

Tenho, nos lugares mais diferentes, amigos à minha espera. Você já reparou que, entre centenas, em cada país, nós temos sempre aquela pessoa, que, sem mesmo saber, espera por nós e, quando nos encontra, é para sempre? Por isso é que eu gosto tanto de viajar, visitar terras que ainda não vi e conhecer aquele amigo desconhecido que nem sabe que eu existo, mas que é meu irmão antes de o ser (BLOCH, 1989, p. 35).

Em relação à viagem para as terras italianas, é isso que acontece. A moderna escritora quer encontrar o que conheceu através dos livros, como se, num confronto com a história e o lugar, ela fosse capaz de unir as duas esferas: realidade e pensamento. Então o resultado é perfeito: celebração da admiração. Assim podemos ler em "Quando a vaga beija o vento...", de 1956, portanto, memória da viagem feita três anos antes, mas escrita como se fosse um instante preservado do tempo, morando na memória. Meireles não descreve os lugares, simplesmente, mas invade outros territórios que os acompanham, reinscreve seus antigos moradores, lembrase de frases por eles ditas, fazendo-os renascer. É desse modo que os locais visitados irão repercutindo em suas recordações como, por exemplo, no texto "Quando a vaga beija o vento...":

Todo o esplendor de Nápoles vai ficando aos nossos pés, na curva do golfo. Poder pensar - tão perto - em Ulisses, na gruta do Oráculo, no túmulo de Vergílio, nos dois Plínios, - um, a morrer sob a lava, procurando salvar as vítimas de Pompeia, outro, a descrever numa carta a catástrofe a que

Doutor em Letras e professor na Escola Superior de Aeronáutica e da Secretaria da Educação do Estado de São Paulo, São Paulo, SP, Brasil. E-mail: lopesdelvanir@bol.com.br 
assistiu... E agora, em Sorrento, a lembrança de Tasso, que aqui viveu, se enlea à pequena canção que continua a aflorar: "No céu azul, a brisa passa, docemente...” (MeIreles, Diário de Notícias, $1^{\circ}$ abr. 1956, p. 1)

As memórias vão sendo despertadas quando Meireles relaciona os lugares visitados às novas impressões vividas. Assim os poemas são gerados, e o material para os seus artigos jornalísticos é reunido. Portanto, o que ela espera encontrar é o que já sentiu e sobre o que refletiu inúmeras vezes. Podemos, então, pensar que as experiências vividas servirão para amplificar o que, de antemão, já estava preparada para encontrar. Tudo o mais, os muros, o gato, o guia, a coleteira, as pedras, a florista, são novos ingredientes que farão eco em seus poemas e artigos. Os ambientes, ainda que inundados de história e de antiguidade, são vivos e aguçam os sentidos da escritora. Nota do jornal $A$ noite trata de salientar que a viagem dela com o marido não é apenas turística. $\mathrm{O}$ vislumbre com a visita renderá vários de seus melhores poemas. Lê-se:

Encontra-se na Itália, não apenas em caráter turístico, mas com a finalidade de colher elementos para a sua atividade literária, a poetisa Cecília Meireles, que viaja acompanhada do seu marido, o professor Heitor Grillo. Cecília Meireles, [sic] ficou impressionada com o que viu e observou na Cidade Eterna e escreveu alguns poemas que talvez sejam dos mais belos que já produziu. Antes de chegar à Itália, visitou a Índia, e recebeu do presidente, Rajendra Prasad, o diploma de doutor "honoris causa" em letras da Universidade de Nova Delhi (A Noite, 15 abr. 1953, p. 5).

Cecília, nos locais que visita na "cidade eterna", revela quais são suas leituras e, nesse movimento, amplia nosso conhecimento e oferece enfoques que o imediatismo da visão poderia encobrir. A partir daí, a leitura dos artigos é permeada por outros olhares, que dialogam com as sensações cecilianas quando está em determinados lugares. Quando em Siena, lembra-se, por exemplo, do que escreveu Montaigne no século XVI, quando por lá passou; ou ainda, quando trata de unir, na memória, traços de Roma e Ouro Preto, realizando uma espécie de diálogo poemático entre Metastasio (1698-1782), Marcial (40-104) e Vergílio (7o a.C.-19 a.C.) com os árcades Cláudio Manuel da Costa (1729-1789), Tomás Antonio Gonzaga (1744-1810) e Alvarenga Peixoto (1744-1792):

E assim caminho, relembrando liras de Gonzaga, versos italianos de Cláudio (sic) Manuel da Costa, e a tradução que Alvarenga Peixoto fez, da "Merope" de Maffei. E assim recordo a Arcádia e tudo quanto existiu no século 18, entre Minas e a Itália. Mas são coisas longas demais para se escrever (Meireles, Diário de Notícias, 29 set. 1955, p. 1).

Portanto, o trabalho de intertextualidade, nos textos referentes à Itália, demonstra o quanto Meireles já conhecia sobre a terra em que esteve, fisicamente, pela primeira vez. Seu relato de viagem deixa de ser linear e apenas descritivo e passa 
a revelar um viés que demonstra, sobretudo, amor pela cultura, pela gente e pelo local para onde viajou. Faz sentido a declaração de que "a poetisa viaja pela Itália e escreve com a atitude de quem está regressando às suas raízes mais profundas, para usar a metáfora fitomórfica tão cara a Sérgio Buarque de Holanda" (MARAFon; Sotratti; FACCiOli, 2014, p. 12). O poema "Caminhante" é uma declaração da busca de tais raízes. A autora carioca se sente parte de cada coluna, de cada pedra, de cada ruína, está em cada estátua, em cada fonte, em cada muro, em cada passo, que parece ser o de redescoberta:

Ando em ti, Roma de altos ciprestes e largas águas, como atrás de mim mesma,

algum dia, depois da minha morte.

Encontro meus próprios anjos

e asas abertas em cada esquina

e meus olhos com pálpebras de pedra,

em cada fonte:

- cheios até a borda.

Contemplo minhas abatidas colunas,

e a nenhuma porta paro,

e sobre nenhum jardim suspiro mais.

Ando em ti, Roma dos altos sonhos e das largas ruínas, como atrás de mim mesma.

atrás de um outro destino.

Ando, ando, ando,

e sinto a extensão de meus antigos muros

e, com profunda pena,

escuto a longa tuba mitológica

derramando para nuvens efêmeras

dispersas notícias atrasadas

de inútil Gloria e possível Amor (Meireles, 1968, p. 99).

Em Poemas italianos, livro fruto da viagem à Itália, o eu-lírico confunde-se com a própria autora. E sabemos disso pelos tantos artigos publicados no carioca Diário de Notícias que se comunicam com os poemas, continuamente, autoesclarecendose. Roma, o primeiro e principal lugar da visita, está ligada ao amor e provoca um sentimento de pertencimento muito forte naqueles que a visitam. Em vista disso, Cecília lembra-se da brincadeira dos tempos de criança quando está na cidade eterna. Esse é apenas um dos 27 poemas dedicados à cidade de Roma, a mais famosa cidade do Lácio:

Lembrai-vos dos velhos dias terrenos, dos primeiros dias humanos, quando principiávamos a brincar com o alfabeto, quando tomávamos conhecimento do planeta redondo, a girar no seu eixo de ferro, em cima da mesa 


\section{$[\ldots]$}

ROMA

AMOR

A cidade está aqui. E o amor?

Que amor? Que amor? - dizei (MEIRELES, 1968, p. 75).

Em A lição do poema, a escritora, em carta a Armando Côrtez-Rodrigues datada de 10 de março, já diz ser este o seu primeiro dia em terras italianas. Por meio dessas tantas missivas enviadas por ela ao seu poeta e amigo "Almirante", ficamos sabendo que ela não viajou com o marido, Heitor Grillo, em dezembro do ano anterior, para se encontrarem no dia 21 de fevereiro de 1953, já em Nova Delhi. Atentemos para a cronologia e as informações de suas cartas ao escritor açoriano:

Roma, 10 de março de 1953: "Roma está lindíssima, porém o frio é grande. [...] A minha janela dá para os verdes da Villa Borghese - mas no primeiro plano é o muro da Porta Pinciana que se estende, com um pouco de vegetação entre os tijolos, grudados por um secular silêncio. Estamos no Hotel Flora, Via Vittorino Veneto- mas não escreva para cá, nem para Lisboa - que será nosso último ponto, na Europa!” (SACHET, 1998, p. 213).

Roma, 1 de maio de 1953: "Vamos ficar por aqui até ao dia 10, para que meu marido termine as visitas oficiais. Depois iremos para Portugal, atravessando Bélgica, França e Espanha. Bem queria ir aos Açores, mas não posso prometer nada, porque sou uma simples acompanhante" (SACHET, 1998, p. 214).

A viagem à Itália deu-se no ano de 1953, logo após a viagem à Índia. Cecília Meireles, acompanhada de seu marido Heitor Vinícius da Silveira Grillo (19021971), e ciceroneados, ao que tudo indica, pela amiga Mercedes La Valle, visitou doze lugares no espaço de dois meses. Na região do Lazio, central, Roma; na região da Toscana, ao norte, Cecília esteve nas províncias de Pistoia, Firenze, Pisa e Siena (inclusive San Gimignano); na Lombardia visitou Milão; na região da província de Veneto, a escritora foi a Venezia. Ao sul, esteve na Campânia, conhecendo Nápoles, Pompeia, Sorrento e Salerno. O percurso foi feito, boa parte dele, com amigos e de automóvel, segundo Bizzarri e as informações coletadas junto ao marido de Cecília quando da edição do livro, em 1968.

Cecília chegou a Roma no fim de março, quando apareciam os primeiros sinais da primavera. Mercedes La Valle descreveu como foi o itinerário na "cidade eterna":

Iniciamos os nossos passeios entre as igrejas e as pedras das ruínas seculares. Fomos ao longo do Tevere que corria lento e solene. Entramos na Villa Borghese. O Giardino del Lago estava azul de hortênsias, rico de plantas seculares, cheio de sombras e de mistérios. Realizado o desejo de Cecília de imergir na primavera romana, dirigimos os nossos passos em 
direção à Poesia, visitando, na piazza di Spagna, a casa onde o poeta inglês John Keats havia morado na Itália, ainda adolescente, na tentativa vã de recuperar a saúde (MEIRELES, 1991, p. 9, tradução nossa).

Um dos primeiros lugares em que a escritora e o marido estiveram foi a casa em que moraram os poetas ingleses John Keats (1795-1821) e Percy Bysshe Shelley (1792-1822). " "Cecília Meireles permaneceu profundamente emocionada ao visitar os lugares onde o jovem poeta escreveu odes e poemas narrativos que se classificam entre as expressões mais perfeitas do romantismo inglês" (MeIreles, 1991, p. 9, tradução nossa). A respeito do episódio, o texto "Piazza di Spagna, 26", refere-se ao endereço da habitação do poeta em Roma, ao lado direito da Piazza di Spagna:

Assim, neste pequeno quarto, assistido apenas por seu amigo, o pintor Severn, morreu este poeta para quem cada dia não tinha o mesmo valor que para os outros homens: porque cada dia, para um autêntico poeta, é um descobrimento, uma invenção, um novo ponto de vista no mundo dos homens, uma seta desfechada na direção dos secretos mundos. [...] A linda casa é a sua definitiva casa - deles e de Severn, o amigo fiel, que sofreu, lado a lado, a agonia do poeta, desde a sua partida da Inglaterra no barco de saudade, na quarentena de Nápoles, na viagem de Nápoles a Roma (Meireles, Diário de Notícias, 6 nov. 1955, p. 1).

Portanto, habitaram na casa Keats e Shelley, sendo que o primeiro morreu pela tuberculose na cama do referido quarto e a casa foi transformada em museu em 1906. No local há manuscritos, esculturas, pinturas, obras e uma grande biblioteca romântica. No centro da Piazza está a Fontana della Barcaccia ${ }^{2}$ (Meireles, Diário de Notícias, 25 set. 1955, p. 1), do início do Barroco e de autoria de Pietro Bernini e seu filho, Gian Lorenzo Bernini. Na mesma praça também ficava a residência de Giorgio de Chirico (1888-1978), ao lado da de Keats. Ele pertenceu à pintura metafísica, surrealista, e trouxe temas melancólicos e enigmáticos nos títulos das obras. ${ }^{3}$ No texto de Meireles, lemos a respeito do pintor grego:

O pintor de Chirico vive, em Roma, nesta formosa Piazza di Spagna, e ao lado mesmo da casa que, por um breve tempo, habitou Keats, e hoje é um pequeno, saudoso museu de sonho, rico de delicadas recordações. Subiremos muitas, muitas escadas para chegarmos à sua porta e, [...] sentimos que, das paredes do corredor, nos observam as mil figuras que o povoam, as mil figuras que ali vivem mitologicamente, sujeitas ao poder do seu criador, de seu dono que, além da pintura, parece possuir outros dons, mais

1 As referências a Keats estão no artigo "Minas em Roma", "Roma, turistas e viajantes" e, sobretudo, em "Piazza di Spagna, 26" e "À sombra da Pirâmide de Cestius".

2 "Na Piazza di Spagna, a fonte, em forma de barca, todos os dias me sugere que foi posta ali, à porta de Keats, para levá-lo, com seu invisível barqueiro, ao país da Glória, com que talvez não sonhasse naquela dolorida mocidade".

3 O enigma da hora (1912), Melancolia de uma bela tarde (1913), Piazza d'Itália e melancolia outonal (1915), por exemplo. 
subtis, de visionário e mágico. [...]

Tudo isto é uma espécie de prólogo para desabafarmos os nossos próprios sentimentos em relação à obra de de Chirico. Seja qual for o motivo tratado, a experiência comunicada, o que sempre nos impressionou diante de seus quadros foi o abismo de solidão e silêncio que neles se abre ao nosso olhar (Meireles, Diário de Notícias, ${ }^{\circ}$ jan. 1956, p. 1).

Depois a escritora visitou, no Cimitero Degli Inglesi, o túmulo do young english poet, poeta Keats, que lhe inspirou o poema “...Writ in water...", parte do epitáfio da sua sepultura em Roma - Here lies one whose name was writ in water ${ }^{4}$ - que faleceu em 1921, aos 26 anos, e foi sepultado em Roma, no Cemitério Protestante.

Há um nome nas águas:

- um nome de poeta.

Um nome nas fontes

cantantes de Roma,

líquida pulseira

das ninfas de pedra.

[...] (MEIRELES, 1968, p. 91)

Mercedes lembra, ainda, da visita às fontes romanas, que "Cecília amava molto", em especial a Fontana de Trevi: "A Fontana di Trevi era o lugar do seu encontro preferido onde ela gostava de escutar as fábulas marítimas de Netuno e dos seus tritões. Ela tinha, assim, imagens de fantasia transfiguradas que evocavam fugas impossíveis sobre 'cavalos fabulosos que fugiram pelos séculos'” (MeIreles, 1991, p. 13, tradução nossa). Cecília escreve, em "Fontana di Trevi”:

Aqui, onde chegam os cavalos mitológicos

evadidos dos séculos,

com ferraduras de berilo e de topázio,

e de olhos desvairados

pelo espetáculo do mundo momentâneo (MEIRELES, 1968, p. 73).

Na busca de si mesma, a Fontana di Trevi tem um sentido mais do que especial: "Aqui me refugio,/ frígida forja de cristal,/ cheia de chispas de espuma (Meireles, 1968, p. 73). Em vários artigos, Meireles remeteu-se à Fonte, indicando sua paixão pelo lugar:

E continuo para a Fontana di Trevi. Lugar do meu encanto, onde gosto de ouvir todos os dias novas fábulas marítimas de Netuno e seus tritões. [...] - e segui para a Fontana de Trevi que é uma espécie de residência minha, onde fico, em imaginação, não à margem, onde sou vista, mas entre as águas, de tantas cores e tantos sons. (Meireles, Diário de Notícias, 29 set. 1955, p. 1 e p. 4)

4 Tradução: "aqui jaz aquele cujo nome foi escrito na água". 
No artigo "Roma, turistas e viajantes", a autora demonstrou ainda mais sua paixão pelo local:

Para o viajante, a Fontana di Trevi é uma aparição mitológica, - aparição que ele não se cansa de verificar [...] a fonte é um festival de deuses, entre águas sussurrantes que surgem por todos os lados, prateados, verdes, espumantes, encaracoladas, sob o olhar de Netuno circundado de tritões e de cavalos que ainda estão saindo do mármore... Porque a Fontana di Trevi é um teatro de água e mármore diante do qual o viajante deslumbrado pensa no papa que a mandou construir, nos artistas que a criaram, nessa água que Agripa mandou canalizar de longe, para os seus banhos, e nos namorados que agora a bebem, com a esperança de fazerem durar o amor (Meireles, Diário de Notícias, 11 set. 1955, p. 1).

Em Roma, vai Meireles ao Bosco Parrasio, construído em terreno doado pelo rei de Portugal, D. João VI, em 1725, o que leva a uma união com interesses intelectuais e políticos, dos árcades lusitanos aos italianos. ${ }^{5} \mathrm{O}$ poema que se refere aos árcades, em Poemas Italianos, é "Cores", em que as estátuas desses escritores se reuniriam para um banquete, com vinhos e frutas, junto à natureza:

Tudo à espera, entre os vigilantes ciprestes

e as derrubadas colunas,

que as estátuas desçam das arquitraves,

dos jardins, das escadas, das fontes,

e venham reclinar entre os jacintos,

para a merenda vesperal,

a brancura da sua nudez feliz (Meireles, 1968, p. 71).

La Valle descreve o caminho percorrido até chegar à Arcádia, que não foi fácil:

A busca do "Bosco Parrasio" foi trabalhosa. Para chegar lá, tivemos que percorrer o ponto mais característico de Trastevere, próximo à Porta Settimiana, e como a Arcádia teve suas primeiras origens nas reuniões na casa da rainha Cristina da Suécia (que recebia no seu palácio de Roma os mais famosos escritores da época), fomos em busca desse palácio que se localiza em uma das ruas mais evocadoras de Roma: "a Lungara", a primeira das ruas criadas pelos Papas do Renascimento (Meireles, 1991, p. 14, tradução nossa).

A Via della Lungara é uma estrada que liga a Porta Settimiana com a Piazza della Rovere, no Rione (Distrito) Trastevere. Na Lungara está o Palazzo Corsini, que no século XVII era morada de Cristina da Suécia e, em cujos jardins, a partir de reuniões entre os literatos, surgiria a Accademia dell'Arcadia. O artigo "Minas em

5 As referências a este episódio estão nos artigos "Pequenas Notas", que se refere a Cláudio Manuel da Costa e Tomás Antonio Gonzaga e, sobretudo, em "Minas em Roma", em que novamente a autora trabalha com Metastásio, Gonzaga, Cláudio Manuel da Costa e Alvarenga Peixoto, lembrando-se do episódio da Inconfidência Mineira e da relação com os árcades de Ouro Preto. 
Roma" trata de ao menos três das igrejas de peregrinação do Distrito Trastevere: Santa Maria, uma das mais antigas de Roma, Santa Cecília e Santa Maria Maggiore. Sobre a última, a viajante escreve:

Tudo em redor de mim tem uma história prodigiosa. Muitas coisas que ora brilham sob este leve sol dourado nasceram de sonhos e visões: numa noite de agosto, a Virgem apareceu a um homem que desejava oferecer sua riqueza a Deus, e aconselhou-o a construir uma igreja onde, no dia seguinte, nevasse. Como esperar neve em agosto? Mas também ao Papa a Virgem apareceu, dizendo-lhe que fosse ao Esquilino, onde haveria neve. E foi assim que, no século IV, foi levantada a igreja de Santa Maria Maggiore (Meireles, Diário de Notícias, 29 set. 1955, p. 1). ${ }^{6}$

No poema "Ah! Santa Maria", a escritora trata do famoso Rione XIII, Trastevere, localizado na margem oeste do rio Tibre e ao sul do Vaticano. Trata-se de um distrito com ruas estreitas e paralelepípedos. A vida noturna é agitada, repleta de bares e restaurantes que servem pratos da culinária romana e italiana em geral, tudo reunido, principalmente, na Piazza di Maria in Trastevere, em que está, também, a Basílica com o mesmo nome. Portanto, une-se o antigo com o contemporâneo. É assim que a poetisa escreve, em um fragmento do poema:

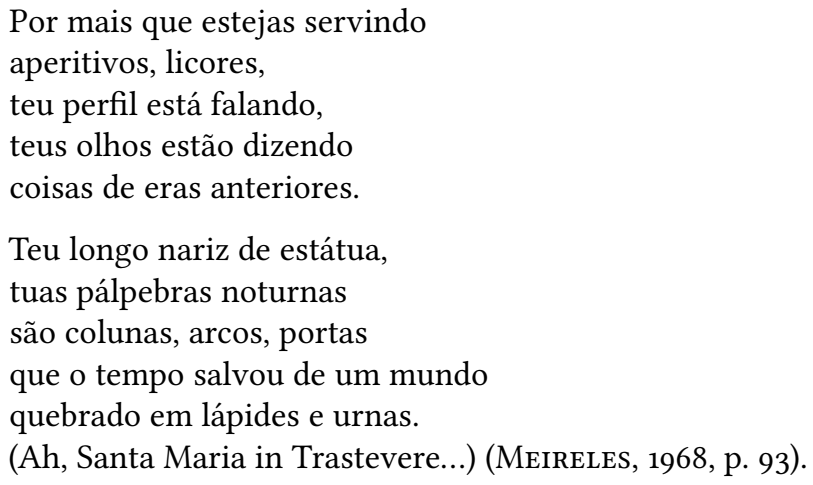

Por fim, a última igreja à qual a escritora faz menção, nesse passeio pelo Trastevere, é a Igreja de Santa Cecília. Para Mercedes La Valle, a escritora brasileira demonstrou, "durante a sua visita na Itália, um profundo sentido de misticismo que chamou sua atenção sobre páginas antigas da vida religiosa, assim se aproximou com humildade da memória de duas santas que tinham lutado contra a lisonja da vaidade terrena: Santa Cecília e Santa Clara" (Meireles, 1991, p. 11, tradução nossa). ${ }^{7}$ O relato biográfico da santa comove a escritora, a ponto de ela elaborar o Romance de Santa Cecília, publicado apenas em 1957, mas que fora escrito

\footnotetext{
6 Por causa do episódio, tido como milagre, a Igreja também ficou conhecida como Madonna della Neve. O ano era 358 a.C. e o Papa da época era Liberio. O dia em que nevou foi 5 de agosto. Para relembrar o fato, atualmente em um espetáculo na praça diante da basílica, cai neve artificial na noite de verão romano.

7 Cecília escreveu o Pequeno oratório de Santa Clara, publicado em 1955.
} 
em 1953, em Roma. Foram editados 200 livros, todos numerados e assinados pela autora. No artigo de O Estado de S. Paulo, Heitor Grillo, professor e marido de Cecília, também se pronunciou sobre o poema e sobre a Santa:

Contou o professor Heitor Grillo que, na Igreja de Santa Cecília, a poetisa passou mais de 3 horas percorrendo e ouvindo do vigário a vida e o martírio da santa. "Cecília ficou tão impressionada - comentou o professor - que, retornando ao hotel, escreveu o Poema de Santa Cecília num jato" (Inspiração de Cecília, a lembrança dos pracinhas. O Estado de S. Paulo, 12 mar. 1969, p. 10).

Cecília Meireles, estando hospedada na Via Vittorio Veneto, está próxima à Villa Borghesi e, assim, tem muita história em que se inspirar: "A minha janela dá para os verdes da Villa Borghese - mas no primeiro plano é o muro da Porta Pinciana que se estende, com um pouco de vegetação entre os tijolos, grudados por um secular silêncio" (SACHET, 1998, p. 213). Na Villa Borghese, escreve sobre o Tempietto di Diana, de 1789, que tinha uma estátua de mármore da deusa da caça ao centro, em tamanho natural, cópia do original perdido, em bronze. A estátua do templo, na Viale della Casina di Rafaello, foi doada pelo Papa Paulo IV para o rei Henrique II da França - como sutil alusão à sua amante, Diana de Poitiers - em 1556. Em 1798, tornou-se parte do acervo do Museu do Louvre, em Paris. Portanto, Cecília não deve ter visto a estátua da deusa Diana quando na Villa Borghese. A escritora viajante, que já havia dedicado outros poemas a Diana, como em Mar Absoluto "Diana" e "Obsessão de Diana" - escreve novamente sobre a deusa virgem da caça e, mais tarde, associada também à lua e à magia:

Quando a flor do seu gesto for partida, será mais pura e desinteressada, e ainda mais a amaremos, ofendida, pelo que foi, na perfeição passada. Era o ritmo invencível da corrida por mais que parecesse estar parada. Explícita, talvez. Nunca entendida:

- livre no tempo, e em pedra aprisionada (MeIRELES, 1968, p. 127).

Ainda na Villa Borghese, a autora foi ao Museo e Galleria Borghese, em que a Galleria degli Imperatori lhe inspira a escrever "Assembleia de Pórfiro" e "Alabastro", poemas que fazem referência aos materiais utilizados para a escultura dos 18 bustos, o pórfiro e o alabastro, realizadas no século XVII por vários autores. O museu se localiza na Piazzale Scipione Borghese, 5, e na sala IV, também chamada de Sala degli Imperatori, a maior e mais decorada do museu, estão os bustos dos césares, dispostos ao longo das paredes. A cor avermelhada do pórfiro, presente nos bustos, é que chama a atenção da escritora. O mármore é salpicado de manchas esbranquiçadas ou de várias cores. O ambiente gelado, já que todo em mármore, contrasta com a "presença" de tantos personagens históricos, que parecem querer acordar, tamanha a perfeição com que foram esculpidos: 
Apenas eu cheguei, carregada de inverno.

Apenas eu respiro nesta fria sala de mármore.

Fria de morte.

Não vos perturbeis, grandes, imóveis, duros bustos de pórfiro,

fino perfil de Augusto,

gorda cabeça de Nero,

imperadores reunidos nesta anacrônica assembleia,

com máscaras cor de mosto,

cor de remoto sangue (MEIRELES, 1968, p. 67).

O poema "Alabastro" também foi escrito por ocasião da visita à Villa Borghese Pinciana, em 14 de março de 1953, destacando os jardins da Villa que, a princípio, acomodava uma grande coleção de obras de arte. No século XIX, Camilo Borghese, então cunhado de Napoleão, vendeu esculturas e antiguidades da Villa Borghese ao imperador francês. Mas há ainda trabalhos de Pietro Bernini (1562-1629) espalhados pelas avenidas da Villa, esculturas de Goethe e Victor Hugo, fontes decoradas, um templo dedicado a Esculápio, entre tantas outras atrações.

Outro poema, "Ceres abandonada", faz alusão, provavelmente, às ruínas do templo dedicado a essa deusa dos cereais, das plantas, da agricultura. Existiu um templo dedicado a Ceres no Monte Aventino, em Roma. Segundo Armellini: "Sulle rovine d'un antico tempio do Cerere, di cui restano tuttora in piedi alcune collone con i capitelli, fu ereto quel nobilíssimo tempio dedicato alla Ss. Vergine, che da molti secoli porta il titolo do S. Maria in Cosmedin" (ARMELLINI, 1887, p. 391). Portanto, uniu-se o templo pagão com o templo cristão. No poema ceciliano "Ceres abandonada", dedicado à deusa, podemos ler sobre o abandono do antigo templo:

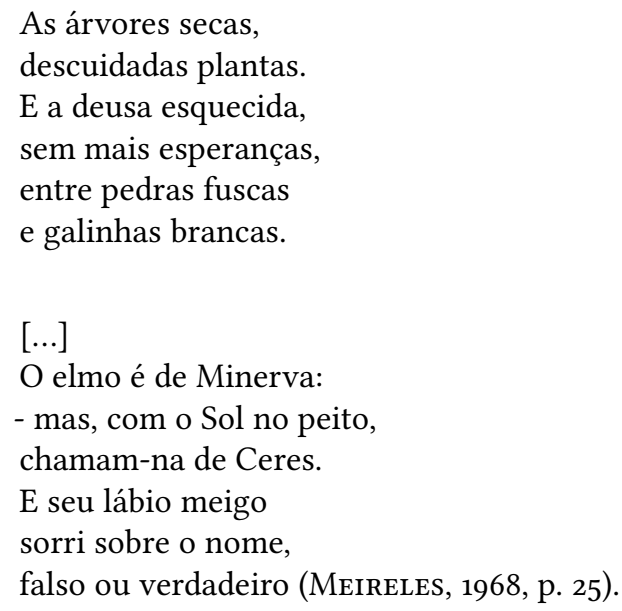

A Via Appia homenageia em seu nome o político Appius Claudius Caecus (340 a.C.-273 a.C.), mas também foi chamada de Regina Viarum (Rainha das Estradas), porque chegou até Brindisi, num total de 600 quilômetros de extensão, sendo uma das grandes obras da engenharia do mundo antigo. Muitos trechos da 
estrada ainda são conservados, acessíveis e muito visitados pelos turistas. No artigo "Nem sempre..." assim escreveu Cecília Meireles: "Deixar que a poeira da Via Appia encoste em nosso rosto partículas que pertenceram a vidas variadíssimas, que se levantam da terra agreste, das estátuas partidas, dos túmulos seculares, e sentir a solidariedade do pó que somos e seremos" (Meireles, Diário de Notícias, 20 nov. 1955, p. 1). ${ }^{8}$ Ao longo da estrada, próximo a Roma, há inúmeras tumbas e catacumbas das primeiras comunidades cristãs romanas, cemitérios sob a terra, do final do século II d.C., localizadas fora dos muros da cidade. Elas são ligadas por numerosas galerias subterrâneas - por cerca de $20 \mathrm{~km}-$ em cujas paredes há tumbas que podem conter um ou mais cadáveres. "Pedras não piso, apenas:/ - mas as próprias mãos que aqui as colocaram,/ o suor das frontes e as palavras antigas./ Ruínas não vejo, apenas:/ - mas os mortos que aqui foram guardados,/ com suas coragens e seus medos da vida e da morte (Meireles, 1968, p. 69). A escritora, no poema "Habitantes de Roma", trata do povo romano que se reunia nas galerias subterrâneas fora da cidade:

Eis um povo de cinza, por toda a parte, um vasto povo subterrâneo, que se levanta na alta noite de Roma, que sobe à flor da terra, que vem de túmulos e catacumbas [...] (Meireles, 1968, p. 83).

As catacumbas, mais de sessenta - embora as mais conhecidas estejam na Via Appia e Via dell'Ardeatina -, são ricas em esculturas, afrescos e epígrafes, sendo testemunhas de costumes e usos da igreja primitiva. Na Via Appia também visitou a Igreja Santa Maria delle Piante, mais conhecida como Igreja Quo Vadis, pois se acredita que o apóstolo Pedro, ao fugir do martírio, tenha visto, nessa Via, Jesus que lhe disse, ao ser questionado para onde iria, que a Roma, para ser novamente crucificado.

E ao sul, além das Igrejas e da ida ao Cimitero Acattolico, a autora carioca ainda esteve no Colosseo e no Arco de Constantino, locais aos quais dedicou seus versos. Colosseo - também conhecido como Anfiteatro Flavio - é uma estrutura oval localizada bem no centro de Roma, próximo ao Fórum. O lugar poderia abrigar até 8o mil pessoas e foi usado para combates entre gladiadores e espetáculos públicos: caçadas, batalhas navais, lutas de animais e execuções, além de jogos. Deixou de ser utilizado durante a Idade Média. Foi Beda, monge inglês e doutor da Igreja, quem escreveu a famosa frase a respeito da arena: "Quamdiu stat Colysaeus stat

8 Em "Saudades futuras", Cecília Meireles praticamente repete a mesma ideia: "Saudades grandes, as da agreste Via Appia, com seus túmulos e estátuas partidas, com sua poeira colada ao nosso rosto. Que partículas veem nesta poeira de tantos séculos? Se nos sentássemos aqui para recordálos, nunca mais nos levantaríamos. De tudo o que passou por este caminho agora solitário, imagens, palavras, gestos ressuscitam" (Diário de Notícias, Rio de Janeiro, 19 fev. 1956, Suplemento Literário, p. 1). Ainda em "Roma, turistas e viajantes", a escritora retoma o pensamento: "O turista [...] ainda está ali, a pensar na Via Appia, no vento que revolve aquele chão de poeiras ilustres" (Meireles, Diário de Notícias,Rio de Janeiro, 11 set. 1955, Suplemento Literário, p. 4). 
Roma; quando cadet Colysaeus cadet Roma et mundus" - "Até quando existir o Coliseu, existirá Roma. Quando o Coliseu cair, cairá Roma. Quando cair Roma, cairá o mundo inteiro" (BEDA apud Polidoro, 2016, p. 7, tradução nossa). Para o Colosseo, Cecília escreveu um poema longo:

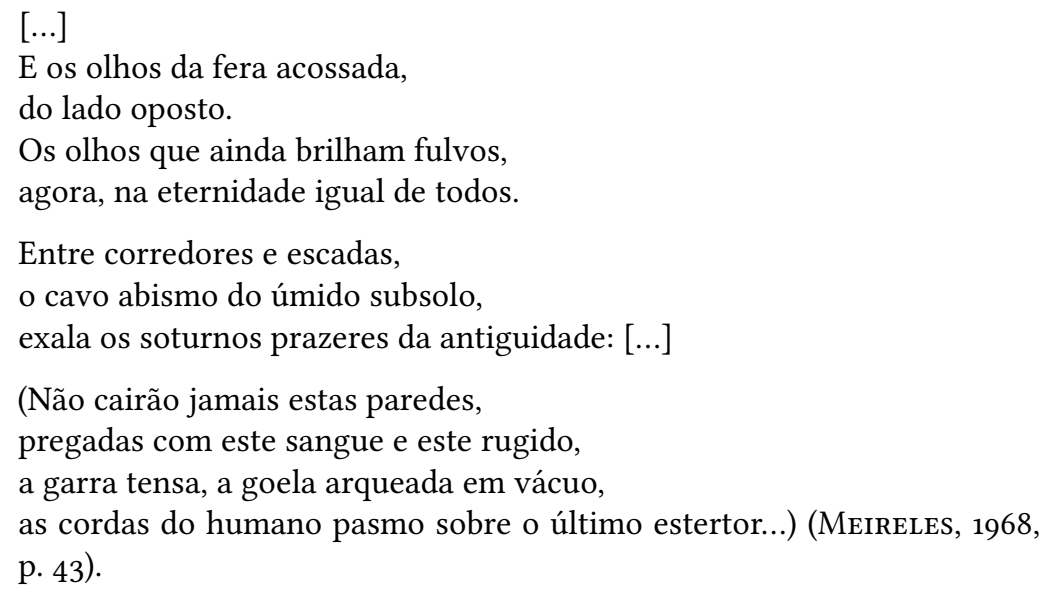

Próximo ao Coliseu está o Arco dedicado a Constantino I (Constantino Magno ou Constantino, o Grande - 272-337), também conhecido como Arco do Triunfo, narrando os gestos heroicos da batalha de Mílvia (312) contra Marco Aurelio Valério Massenzio (278-312). Entendemos que o poema "Arco" faça referência ao imperador Constantino:

Do imperador que passou, não há vestígios:

- e foi tão poderoso.

Mas o vento que dançava nas pregas do vestido

- e um vento leve! -

continua a dançar ali (MeIRELES, 1968, p. 30).

Na mesma região estão as Termas de Caracalla, que ficam na mesma área do Coliseu, dos Arcos de Constantino e de Tito, da Coluna de Trajano, do Fórum Romano e do Circo Máximo, da Porta São Paulo e da Pirâmide de Cestius, entre tantos outros monumentos. Ainda que Cecília não tenha dedicado nenhum dos seus poemas às Termas, escreveu sobre elas em "O habitante de Caracalla", dedicado às ruínas do lugar. Após descrever o que sobrou do recinto e as atitudes do imperador tirano Caracalla, voltou-se para os escritores George G. Byron (1788-1824) e John Keats (1795-1821). Recordou o "Prometheus Unbound", de Shelley (1792-1822), publicado em 1820 e escrito, segundo consta em pintura de Joseph Severn (1793-1879), nas Termas de Caracalla: "é Shelley que continuamos a ver, sentado na solidão, com a pena cheia de versos, e a alma transbordante de generosidade. [...] Na imponência do instante romano que criou estas velhas Termas, o jovem poeta, na sua 
vida livre, realiza o milagre da sobrevivência do espírito da imortalidade da poesia. O mais, ruínas. Grandiosas, é certo" (MeIreles, Diário de Notícias, 29 jan. 1956, p. 1).

As Termas remetem aos aquedutos romanos que dão nome a um dos textos de Poemas italianos, embora escrito dois anos após a viagem, já no Rio de Janeiro. Não há, nos artigos de Cecília Meireles dedicados à Itália, nenhuma menção a estas estruturas notáveis do mundo antigo, que permitia o transporte das águas para abastecer banhos públicos, chafarizes e poucas residências privadas. $O$ primeiro aqueduto foi inaugurado em 19 a.C., o Acqua Vergine, construído por Marcus Vipsanius Agrippa (63 a.C.-12 a.C.), e abastecia um banho público em Roma. A Fontana di Trevi, bem como a Fontana della Barcaccia, na Piazza di Spagna, são abastecidas por esses aquedutos. No século III a.C., Roma contava com onze aquedutos para abastecer uma população de quase um milhão de pessoas na época traiana (de Marcus Ulpius Nerva Traianus -56 d.C.-117 d.C., imperador de 98-99 a 117 d.C.). ${ }^{9}$ Sobre os aquedutos, Sesto Giulio Frontino (?3o d.C.-10o d.C.) escreveu em De aquis, I, 16: "Essa quantidade de estruturas que transportam tanta água, compare, se quiser, com as pirâmides ociosas ou com outras obras inúteis, se bem conhecidas, dos gregos" (apud HARRIS, 2013, p. 233). ${ }^{10}$ Sobre tais estruturas, Cecília escreveu o poema "Os aquedutos", lembrando-se dos arcos que vão se deteriorando com o tempo:

Pela campanha romana caminham os aquedutos.

Grandes passadas de pedra de horizonte a horizonte.

Despedaçados aquedutos, velhos escravos de mãos dadas que um dia transportaram a água, eternamente livre. $[\ldots]$

Ainda caminham pela campanha romana os aquedutos em ruína, dia e noite, dia e noite, nas quatro estações do ano, até que seja dissipada a última pedra. Agora conduzem a memória dos tempos e dos homens, o pensamento dos viajantes que o contemplam, a lição da vida, nos velhos, inutilizados arcos... (Meireles, 1968, p. 111).

No entorno da cidade eterna, em Tívoli, a aproximadamente $30 \mathrm{~km}$ de Roma, Meireles conhece Villa d'Este, um antigo convento franciscano em estilo maneirista, com majestosos jardins. São mais de quinhentas fontes e esculturas, cercadas por densa vegetação. A Villa d'Este, como é conhecida, foi encomenda do cardeal Ippolito II d'Este (1509-1572), governador do lugar a partir de 1550. Foi dele a ideia dos jardins - que medem 35 mil metros quadrados - nas encostas em declive, re-

\footnotetext{
9 O aqueduto mais velho conhecido é o Acqua Appia, construído em 12 a.C., com 16 quilômetros de extensão e quase todo sob a terra. Outros aquedutos são: Aqua Marcia, Anio Vetus, Acqua Alexandrina, Acqua Tepula, Aqua Iulia, Acqua Alsietina, Anio Novus e Acqua Traiana. Além destes, depois do Renascimento foram construídos outros quatro: Acqua Felice, Acqua Paola, Acqua Pia Antica Marcia, Acquedotto del Peschiera-Capore e Acquedotto Appio-Alessandrino. Há aquedutos ainda conservados também na Ásia Menor, Espanha, França e norte da África.

1o "Tot aquarum tam multis necessariis molibus pyramidas videlicet otiosas compares aut cetere inertia sed fama celebrata opera Graecorum".
} 
pletos de cascatas, tanques de água, lagos, fontes e canais, além de muitas esculturas e espaços cobertos de pinturas. Diz-se que em Villa d'Este acontece uma luta constante entre pedras e águas, pelo grande número de grutas, cavernas e jogos de água, além de música hidráulica, como ocorre com as Fonte de Netuno e a Fontane dell' Organo. O jardim, obra de Pirro Ligorio (?1510-1583) com direção de Alberto Galvani (?-1586), construído como uma sequência de terraços sobrepostos, foi abandonado no século XVIII e meados do século XIX. Após a Primeira Guerra Mundial tornou-se parte do Estado e os jardins foram completamente restaurados, sendo abertos ao público por volta de 1920 . O rio Aniene, junto a nascente Rivellese, alimenta as fontes, jatos de água, canais e lagos do jardim. $\mathrm{O}$ abastecimento de água para o jardim é uma das grandes obras de engenharia romana da antiguidade, já que comporta um aqueduto e um túnel de água sob a cidade, o que cria os jatos de água das fontes sem nenhuma intervenção humana. Fontana del Bicchierone é uma das mais famosas. Lembra uma taça, em cuja base está uma concha. Depois há o complexo de fontes conhecido como La Rometta, a partir da qual se chega à alameda em que estão Le Cento Fontane. A autora, como todos os que visitam os jardins de Villa d'Este, ficou encantada com o número de cascatas, fontes, escadarias, estátuas, a vegetação, o barulho e o frescor do lugar. O dado histórico, os séculos de história presos em cada um destes lugares, leva a escritora a produzir o poema "Descrição (Jardim de água)", no qual podemos ler os seguintes tercetos:

Ainda vejo as estátuas seculares,

entre os ciprestes espumosos de água

atirada em repuxos pelos ares.

[...]

Mil repuxos, mil fontes, mil cascatas...

Água que chora e ri, lágrima e canto, mão diáfana a apagar nomes e datas.

Ainda vejo os degraus, os braços da hera a entrelaçar em muros, sombra, tempo,

Verão, Inverno, Outono e Primavera (Meireles, 1968, p. 57).

E o poder da água, de nascimento e de morte, aparece em três das últimas estrofes do poema, ligada à passagem do tempo, sempre se regenerando. Tais estrofes nos transportam ao "Retrato"11 (MeIRELES, 2017, p. 250), também da autora. Assim continua o poema "Descrição":

E a água passava, rápida e sonora,

- e onde estais, rosto meu, sonho, saudade,

em que lugar da terra estais agora?

\footnotetext{
11 "Eu não tinha este rosto de hoje, /assim calmo, assim triste, assim magro, /nem estes olhos tão vazios, / nem o lábio amargo./ Eu não tinha estas mãos sem força,/ tão paradas e frias e mortas;/ eu não tinha este coração/ que nem se mostra. Eu não dei por esta mudança,/ tão simples, tão certa, tão fácil:/ - Em que espelho ficou perdida/ a minha face?”
} 
Tudo quanto já fomos é levado e vamos sendo aos poucos desprendidos de tudo quanto amamos no passado.

Como em lágrimas foi-se a minha vida pelas escadas d'água resvalante, com tanta pressa e tão sem despedida (Meireles, 1968, p. 57 e 59).

No artigo "Saudades futuras", a escritora faz menção à Villa d'Este. As palavras utilizadas lembram muito as que estão no poema a respeito do "Jardim de água":

Teremos saudades do mundo das águas rumorosas de Villa d'Este, dessas águas que são escadarias, nas cascatas; que são ciprestes, nos repuxos; que falam, cantam, choram, entre as árvores; que são também como um povo encantado, procurando forma estável, correndo atrás de sua própria fala e de sua realização.

Que saudade teremos de tudo isto, desta evaporação dos jardins, desta velhice das estátuas, desta decadência dos deuses (Meireles, Diário de Notícias, 19 fev. 1956, p. 4).

Em diversos poemas, Cecília Meireles faz menção aos muros da cidade de Roma, que serviam como defesa para a cidade. A Mura Aureliane, por exemplo, é uma das mais conhecidas de Roma e foi construída por volta dos anos 271 e 275, pelos imperadores Aureliano (214-275) e Probo (232-282). Com certeza, a escritora e os que a acompanhavam passaram por esta muralha, já que fica localizada no distrito de Trastevere. É um complexo de torres, portões, latrinas, janelas, torres para iluminação e poternas (portas secundárias). A Pirâmide de Cestius e o anfiteatro Castrense e até mesmo partes dos Aquedutos Cláudia e Ânio Novo, na Porta Maggiore, como referência à basílica Santa Maria Maggiore, estão incorporados ao muro. Assim, em alguns versos de seus poemas, encontramos tais referências. No poema "Natureza quase viva", a escritora carioca se dirige aos muros romanos e à chegada da primavera, justamente o período em que ela estava por lá:

Velhos muros romanos, apagai-vos.

Para que brilhem as cores da primavera:

- margaridas, lírios, rosas.

Cravos rendados.

Tulipas oclusas.

Violetas amontoadas, orvalhadas.

Ramos de prunáceas.

Azaleias e orquídeas.

O oloríssimo jacinto (Meireles, 1968, p. 47).

O poema está retratado também no artigo "Todos os caminhos": "De estranho fogo foram impregnados estes muros de Roma, que, apesar do dia sombrio, parece haver em redor da cidade um cinto de sol. E embora faça tanto frio, e as floristas 
estejam tremendo nas suas grossas roupas e no seu robusto corpo, as flores encantadas com o dia, como se tudo fosse orvalho, brilham com uma firmeza de porcelana em suas pétalas róseas, brancas, encarnadas, perfeitas e felizes, nas barracas das esquinas, - sem saberem que estão cortadas" (Merreles, Diário de Notícias, 14 ago. 1955, p. 4).

"Muros de Roma" é outro poema dedicado ao que restou dessas monumentais obras. Parece dialogar, sobretudo, com a citação anterior de "Todos os caminhos", a respeito do sol na tarde. Estabelece-se um contraste entre o passado e o presente, todos perceptíveis nas mesmas paredes: as mãos de quem construiu os muros e as mãos de quem visita e sonha com os muros no tempo atual, sob o sol da tarde em Roma: "Com estas disposições de espírito, folheio antologias italianas, numa tarde que, embora nevoenta, não consegue apagar a luminosidade destes muros romanos, destes velhos muros de onde emergem tufos verdes, que anunciam a primavera" (Meireles, Diário de Notícias, 4 dez. 1955, p. 1). No poema, construído em tercetos, lemos:

\author{
Nos muros da urbe desenham-se as árvores \\ amarelas, ferrugentas, frágeis, \\ quase fósseis. \\ Nos muros da urbe desliza o sol da tarde \\ fria, coroada de vento: \\ esta límpida e frívola tarde atual. \\ $[\ldots]$ \\ Nos muros da urbe dourados de sol, \\ deslizam as mãos póstumas, douradas de sol. \\ Umas com as outras conversam as mãos por cima dos muros. \\ Lembranças do trabalho antigo. \\ Saudade de construir. \\ Nos muros da urbe desliza a sombra dos sonhos de hoje, \\ de horas velozes, \\ na límpida e frívola tarde atual (MeireLEs, 1968, p. 87).
}

Os muros que cercavam a "cidade eterna" ficam impregnados na imaginação de Meireles, motivo pelo qual o tema é recorrentemente trabalhado em outros poemas ao longo do livro, como em "Florista" - "sob os álamos amarelos,/ o longo de muros tão antigos" (MeIreles, 1968, p. 33) - ou "Alabastro" - "Parede de lágrimas no fim do mundo./ Muro de radiosos fantasmas,/ coroas, sagração" (MeIRELEs, 1968, p. 45).

Cecília Meireles mantinha o desejo de voltar à Itália e, particularmente, a Roma. Segundo Mercedes La Valle, nas inúmeras cartas a ela enviadas pela escritora brasileira, sempre havia a manifestação da saudade da città eterna: 
Ano após ano; cartas e cartas que recordavam, quase como um diário, a sua viagem na Itália, exprimiam a sua saudade de Roma: 'Aqueles dias de primavera romana fria permanecerão para ser sempre amados', escrevia Cecília registrando 'o ar perfumado dos ramos de todas as cores que a florista dispunha no banco'. E acrescentava: 'No entanto, desejo que a Primavera venha aos degraus da Trinità dei Monti, ou às margens da minha idolatrada Fontana di Trevi. O vento nunca toca as suas flores (MEIRELEs, 1991, p. 14, tradução nossa).

Em outras cartas, a autora brasileira reitera o pensamento: "Perder Roma significa não só perder uma cidade, mas tudo o que ela representa: sonhos, poesias, tragédia, liberdade, sátira, beleza, fé... Quem pode perder tudo sem se dividir?" (Meireles, 1991, p. 15, tradução nossa). E em outra, de janeiro de 1962: "Ah, como eu gostaria de ver Roma de novo e vou buscar a primavera para os jardins de junquilhos" (Meireles, 1991, p. 15, tradução nossa). Por todos esses desejos, por saber que "sempre se volta a Roma, quando se tem o cuidado de atirar para trás uma moeda de despedida na Fontana di Trevi” (Meireles, Diário de Notícias, 11 set. 1955, p. 1), a escritora carioca escreve: "Estou jogando uma moeda na Fonte de Trevi todos os dias, mas o milagre é difícil, e se eles lhe dissessem que eu morri, não pergunte de quê: foi de melancolia" (MeIreLEs, 1991, p. 15, tradução nossa).

Em carta datada de 27 de março de 1958, a respeito do desejo da escritora carioca rever, particularmente, a Fontana di Trevi, La Valle transcreveu: "Quando voltarei a ver a Fontana di Trevi? A minha felicidade é este poder de amar tantas coisas, grandes e pequenas, distantes e próximas, e de estar sempre disposta a cantar esse amor" (MeIRELES, 1991, p. 14-15, tradução nossa). O que sabíamos é que Cecília não pudera mais retornar à Itália. La Valle também confirmou ao escrever que: "De fato, mesmo não perdendo a esperança, não revê mais Roma, mas continuou a sonhar com 'a saudação do sol em pó de ouro, que se expande sobre todas as coisas na primavera romana; as flores do Jardim do Lago; a estrada Appia com os seus antigos mausoléus'” (Meireles, 1991, p. 15, tradução nossa). Segundo Mercedes, em carta de 1959, a autora brasileira lhe escreveu: "Tenho muita saudade da Itália e gostaria de visitar cidades que ainda não conheço. Naquelas que conheço penso com ternura” (MEIRELES, 1991, p. 15, tradução nossa).

O inusitado em toda essa história é que, em carta enviada para Armando CôrtesRodrigues no dia 15 de março de 1958, portanto, 12 dias antes da que fora enviada a sua amiga Mercedes, Cecília Meireles está em Roma, onde permanecerá alguns dias, vindo de Israel. Teria a autora, portanto, voltado ao lugar de seus desejos, à cidade eterna? Teria visitado a amiga? Teria ido à Fontana di Trevi? Apenas sabemos das palavras da autora na carta enviada da "cidade eterna", em 15 de março de 1958: "Agora vou ficar uma semana em Roma, à espera do avião que partirá no dia 21, e daqui lhe mando estas poucas palavras, desejando que elas o encontrem com boa saúde e muito feliz" (SACHET, 1998, p. 227). Confirma tal fato, uma pequena nota do Diário de Notícias, RJ, do dia 25 de março de 1958: 


\section{Viajantes}

Sra. Cecília Meireles - Procedente de Roma, por via aérea, regressou ao Rio, após demorada estadia em Israel, onde esteve em missão cultural, a sra. Cecília Meireles, escritora e poetisa brasileira (Meireles, Diário de Notícias, 25 mar. 1958, p. 3).

Assim termina a viagem da escritora carioca às terras italianas, que começou antes de 1953 e terminou apenas com sua morte em 1964. A escritora continuou a viajar pelos locais da Itália, lembrando fatos, construindo textos, publicando em jornais, alimentando o sonho da volta. Nesse sentido, cabem bem as palavras de La Valle: "Lembrando nossos caminhos no maio brilhante, entre os mármores de clara luz, as cúpulas e os pinheiros no imenso azul, saímos da história. Atravessemos novamente Roma. O doce entardecer já caiu sobre nós. Vamos caminhar com as memórias" (MeIreles, 1991, p. 23).

\section{Referências}

ArmelLINI, Mariano. Le chiese di Roma: dalle loro origini sino al secolo XVI. Roma: Romana, 1887.

Polidoro, Massimo. L'avventura del Colosseo. Milano: Piemme, 2016.

Bloch, Pedro. Vida, pensamento e obra de grandes vultos da cultura brasileira: entrevistas. Rio de Janeiro: Bloch, 1989.

Dí́RIO DE NotícIAS, Rio de Janeiro: 25 mar. 1958. Segunda Seção.

HARRIS, W. V. The Ancient Mediterranean environment between science and history. Leiden; Boston: Brill, 2013.

A NoITE. Rio de Faneiro, 15 abr. 1953, p. 5.

Marafon, Glaucio José; Sotratti, Marcelo Antonio; Faccioli, Marina. Turismo e território no Brasil e na Itália: novas perspectivas, novos desafios. Rio de Janeiro: EdUERJ, 2014.

MeIreles, Cecília. Poesia completa. São Paulo: Global, 2017.

Meireles, Cecília. Nostalgie Romane - Saudades Romanas. Introduzione e traduzione di Mercedes La Valle. Palermo; São Paulo: Italo-Latino-Americana Palma, 1991.

Meireles, Cecília. Poemas italianos. Tradução de Edoardo Bizzarri. São Paulo: Instituto Ítalo-Brasileiro, 1968.

Meireles, Cecília. Uma hora em San Gimignano. Diário de Notícias, Rio de Janeiro, Suplemento Literário, 13 maio 1956.

Merreles, Cecília. Da ruiva Siena. Diário de Notícias, Rio de Janeiro, Suplemento Literário, p. 1, 29 abr. 1956. 
Meireles, Cecília. "Quando a vaga beija o vento..." Diário de Notícias, Suplemento Literário, $1^{\circ}$ abr. 1956.

Meireles, Cecília. Saudades futuras. Diário de Notícias, Rio de Janeiro, Suplemento Literário, 19 fev. 1956.

Meireles, Cecília. O habitante de Caracalla. Diário de Notícias, Rio de Janeiro, Suplemento Literário, 29 jan. 1956.

Meireles, Cecília. De Chirico. Diário de Notícias, Rio de Janeiro, Suplemento Literário, $1^{\circ}$ jan. 1956.

Meireles, Cecília. Navegação por antologias. Diário de Notícias, Rio de Janeiro, Suplemento Literário, 4 dez. 1955.

Meireles, Cecília. "Nem sempre”... Diário de Notícias, Rio de Janeiro, zo nov. 1955.

Meireles, Cecília. Piazza di Spagna, 26. Diário de Notícias, Rio de Janeiro, Suplemento Literário, 6 nov. 1955

Meireles, Cecília. Minas em Roma. Diário de Notícias, Rio de Janeiro, Suplemento Literário, 25 set. 1955.

Meireles, Cecília. Roma, turistas e viajantes. Diário de Notícias, Rio de Janeiro, Suplemento Literário, 11 set. 1955.

Meireles, Cecília. Todos os caminhos. Diário de Notícias, Rio de Janeiro, Suplemento Literário, 14 ago. 1955.

SAchet, Celestino (Org). A lição do poema: cartas de Cecília Meireles a Armando Côrtes-Rodrigues. Ponta Delgada: Instituto Cultural de Ponta Delgada, 1998.

Recebido em 25 de março de 2018.

Aprovado em 17 de setembro de 2019

\section{Resumo/Abstract/Resumen}

\section{Roma pelos olhos de Cecília Meireles}

\section{Delvanir Lopes}

Cecília Meireles é poetisa-viajante. Quando voltava da viagem à Índia, fez uma parada de cerca de dois meses na Itália. Nesse curto período, percorreu diferentes regiões, entre elas: Roma, Nápoles, Pompeia, Sorrento, Florença e Milão. Dos lugares em que esteve, Roma parece ter sido o mais especial, tanto que a escritora alimentava sempre o desejo de retornar à "cidade eterna". Este estudo propõe-se a visitar alguns dos locais em que a viajante esteve e quais as impressões que ela 
teve e que resultaram, muitos deles, em poemas presentes na obra dedicada à Itália: Poemas italianos.

Palavras-chave: Cecília Meireles, Itália, Roma, Poemas italianos.

\section{Rome through the eyes of Cecília Meireles}

\section{Delvanir Lopes}

Cecilia Meireles is a traveling poet. When she was returning from her trip to India, she stopped for about two months in Italy. In this brief period, she traveled through different regions, among them: Rome, Naples, Pompeii, Sorrento, Florence and Milan. From those places where she was, Rome seems to have been the most special, so much so that the writeress always had the desire to return to the "eternal city". This study proposes to visit some of the places where the traveler was, what her impressions were and that result, many of them, in poems present in the work dedicated to Italy: Poemas Italianos.

Keywords: Cecília Meireles, Italy, Rome, Poemas italianos.

\section{Roma a través de los ojos de Cecília Meireles}

\section{Delvanir Lopes}

Cecilia Meireles es una poeta viajera. Cuando estaba regresando del viaje a la India se detuvo durante unos dos meses en Italia. Durante este breve período recorrió diferentes regiones, entre ellas: Roma, Nápoles, Pompeya, Sorrento, Florencia y Milán. De los lugares el los que ella estuvo, Roma parece haber sido el más especial, tanto, que la escritora siempre tuvo el deseo de regresar a la "ciudad eterna". Este artículo propone visitar algunos de los lugares adonde la viajera fue y qué impresiones tuvo, muchas de las cuales resultaron en los poemas presentes en su obra dedicada a Italia: Poemas italianos.

Palabras clave: Cecília Meireles, Italia, Roma, Poemas italianos. 